\title{
Production and Adoption Constraints of Improved Coffee Varieties in Jimma Zone, Southwest Ethiopia
}

\section{Samuel Diro ${ }^{1}$ \\ Beza Erko \\ Kalkidan Fikirie ${ }^{s}$}

'Holeta Agricultural Research Center; Agricultural Economics Research Process, Holeta; Ethiopia. Email:samueldiro85@gmail.com Tel:+251920533748

'Jimma Agricultural Research Center; Agricultural Economics Research Process, Jimma; Ethiopia. Email:beza.erko@yahoo.comTel:+251920021905

${ }^{s}$ Melkassa Agricultural Research Center, Melkassa, Ethiopia.

Email:kalkidanfikire@gmail.com Tel:+251912758580

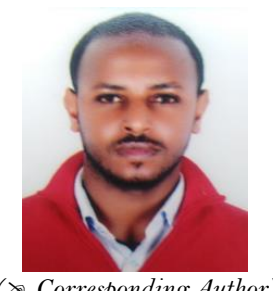

\begin{abstract}
The study was aimed to identify major coffee production problems that affected coffee farmers' production and productivity. It was conducted in four districts of Jimma zone namely Gera, Manna, Limu Kosa and Gomma. Multistage sampling technique was employed to select the population for the study which involved both purposive and random sampling techniques. Data was collected through structured questionnaire administered to sampled farmers from 285 coffee producing households. Both descriptive and inferential statistics were used to analyze the gathered and cleaned data. Kendall's coefficient of concordance was used to rank the most important coffee production constraints. The study has identified three top constraints on coffee production. Low and fluctuating coffee price, lack of coffee market information and lack of preferred coffee seed and seedling varieties were the major problems explored. Strengthening cooperatives and unions, sustainable supply of improved coffee seeds and seedlings, and sustainable coffee seed system are suggested to tackle these coffee production problems.
\end{abstract}

Keywords: Coffee, Constraint, Cooperative, Kendall, Market information, Unions.

Citation | Samuel Diro; Beza Erko; Kalkidan Fikirie (2019). Production and Adoption Constraints of Improved Coffee Varieties in Jimma Zone, Southwest Ethiopia. Agriculture and Food Sciences Research, 6(1): 41-49.

History:

Received: 14 January 2019

Received: 14 January 2019

Accepted: 29 March 2019

Published: 4 June 2019

Licensed: This work is licensed under a Creative Commons Attribution 3.0 License (cc))

Publisher: Asian Online Journal Publishing Group
Contribution/Acknowledgement: The authors would like to gratefully acknowledge Jimma Agricultural research center for the encouragement and support of various kinds. They are very grateful for district coffee experts of Gomma, Gera, Limu Kosa and Manna for their dedication in facilitation and coordination. They also like to thank our collaborators including respondents (farmers), development agents and Kebele officials for their respective contributions.

Funding: The authors would like to thank Jimma agricultural research for the Funding: The aut
financial support.

Competing Interests: The authors declare that they have no conflict of interests.

Transparency: The authors confirm that the manuscript is an honest, accurate, and transparent account of the study was reported; that no vital features of the study have been omitted; and that any discrepancies from the study as planned have been explained.

Ethical: This study follows all ethical practices during writing.

\section{Contents}

1. Introduction

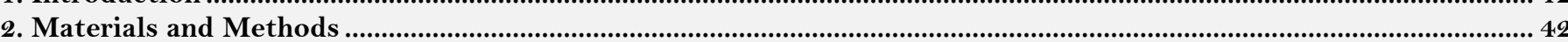

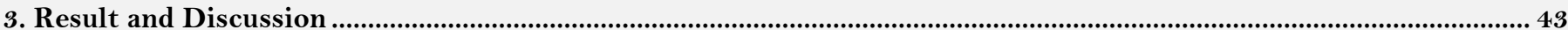

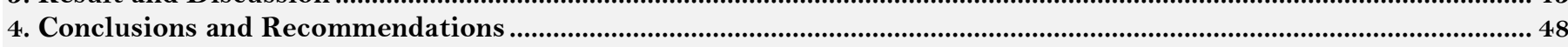

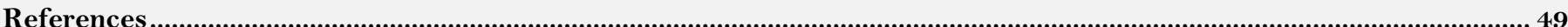




\section{Introduction}

World coffee production is increasing from year to year in spite of huge market volatility and environmental constraints [1]. Arabica coffee has its center of origin in southwestern and southeastern Ethiopia [2, 3]. Ethiopia produces $9 \%$ of world's Arabica coffee with a value of 7.2 million $60 \mathrm{~kg}$ bags annually. Brazil and Colombia ranked first and second with $57 \%$ and $22 \%$ of the total production, respectively [4].

In Ethiopia, coffee is cultivated in four distinct production systems. Garden coffee refers to the bulk of Ethiopian coffee which represents more than 50\% of total coffee coverage. It is grown by smallholder farmers intercropped with cereals, fruits and vegetables in the southern and eastern regions. The last production system is plantation which is grown on large state owned or commercial farms (represents $5 \%$ of production). The plantation production system that mainly observed in the southwestern part of the country under heavy shade and intensive management is based on improved varieties and agronomic practices [5,6].

Pokorná and Smutka [7] reported that international coffee trade does not support the developing or least developed countries [8] pointed out lack of capital, poor extension service, poor market infrastructure, low and volatile coffee price, poor linkage to cooperatives as a major coffee production and marketing constraints. Apart from these, disease and lack of pest control programs also results in decline in coffee production [9].

Jimma agricultural research center has devoted considerable effort and resource, and developed several coffee technology packages. A number of coffee cultivars that combine high yield, disease resistance and quality character were developed by the center. In addition to these technologies, several recommendations have been developed on pest and disease management, agronomic and soil fertility management [10]. Jimma zone is one of the major coffee producing areas of Ethiopia. Despite the dissemination of coffee improved technologies through different coffee extension approaches, utilization of the improved technologies is poor. Intensive study on the constraining factors for coffee production has not been studied using different methodologies. This study was designed to explore constraints of coffee production. The result of the study could be helpful for coffee related biological and physiological researchers, academicians and policy makers.

\subsection{Objectives}

The overall objective of the study is identifying major constraints of coffee production in Jimma zone. The specific objectives are:-

- To identify constraints that hinder coffee production activities on the study area.

- To suggest policy options the way coffee production bottlenecks could be eliminated.

\section{Materials and Methods}

\subsection{Study Area Description}

The study was conducted in four districts of Jimma zone namely Gera, Manna, Limu Kosa and Gomma districts.

Gera district is found in the southwest of Jimma Zone. It shares border with Chekorsa to the south east, with Gomma to the east, with Setema to the north east, with Sigmo to the north west, with Shebe Sombo to the south and the south Ethiopian people's nations and nationalities to the west and south west. Its absolute location ranges between $7^{\circ} 27^{\prime}$ to $7^{\circ} 55^{\prime}$ north latitude and $38^{\circ} 01^{\prime}$ to $36^{\circ} 24^{\prime}$ east longitude. Tropical, Semi tropical and temperate agro climates respectively shares $15 \%, 35 \%$ and $50 \%$ of the district's total area. The mean annual temperature of the district ranges from $15-22^{\circ} \mathrm{c}$. The vast area of the district's annual rainfall varies between $1300 \mathrm{~mm}$ and $1700 \mathrm{~mm}$. Coffee and teff are the major local cash crops in the district.

Limu Kosa district extends between $7^{\circ} 50^{\prime}$ to $8^{\circ} 36^{\prime}$ north latitudes and $36^{\circ} 44^{\prime}$ to $37^{\circ} 29^{\prime}$ east longitudes. It is bordered with Limmu Seka district in north and West Shoa Zone in north east, with Tiro Afeta in southeast, with Manna and Kersa districts in south, with Buno Bedele zone and Gomma district in west. It is situated in the north central part of the zone. Sub-tropical and temperate agro climates do respectively constitute $70 \%$ and $15 \%$ of the district's areas. The remaining $15 \%$ of the district's agro climate does have tropical climate. The mean annual temperature of the district ranges from $18-23^{\circ} \mathrm{c}$. The mean annual rainfall of the district ranges from $1300-$ 2300mm. Maize and coffee are the main crops grown in the district.

Gomma district extends between $7^{\circ} 40^{\circ}$ to $8^{\circ} 04^{\prime}$ north latitudes and $36^{\circ} 17^{\prime}$ to $36^{\circ} 46^{\prime}$ east longitudes. It is bordered with Didesa district in north, with Limmu Kosa district in east, with Manna district in southeast, with Seka Chekorsa in south and with Gera district in west. It is situated in the central part of the zone. Most part of the district belongs to subtropical and temperate agro climates. Sub-tropical and temperate agro climates do respectively constitute $88 \%$ and $12 \%$ of the district's area. The mean annual temperature of the district ranges between $15^{\circ} \mathrm{c}$ and $22^{\circ} \mathrm{c}$. The vast area of the district's annual rainfall varies between $1700 \mathrm{~mm}$ and $2100 \mathrm{~mm}$. Maize and coffee are also the main crops grown in the district.

Manna district extends between $7^{\circ} 38^{\prime}$ to $7^{\circ} 54^{\prime}$ north latitudes and $36^{\circ} 38^{\prime}$ to $36^{\circ} 53^{\prime}$ east longitudes. It is bordered with Gomma and Limmu Kosa districts in north, with Kersa district in east, with Seka Chekorsa district in south and with Gomma district in west. It is also situated in the central part of the zone. Sub-tropical and temperate agro climates do respectively constitute $80 \%$ and $20 \%$ of the district's total areas. The vast part of the district does have with mean annual temperature ranges between $18^{\circ} \mathrm{C}$ and $20^{\circ} \mathrm{C}$. The district has mean annual rainfall which lies between 1300 and $1700 \mathrm{~mm}$. Maize and coffee are the main crops grown in the district [11]. 


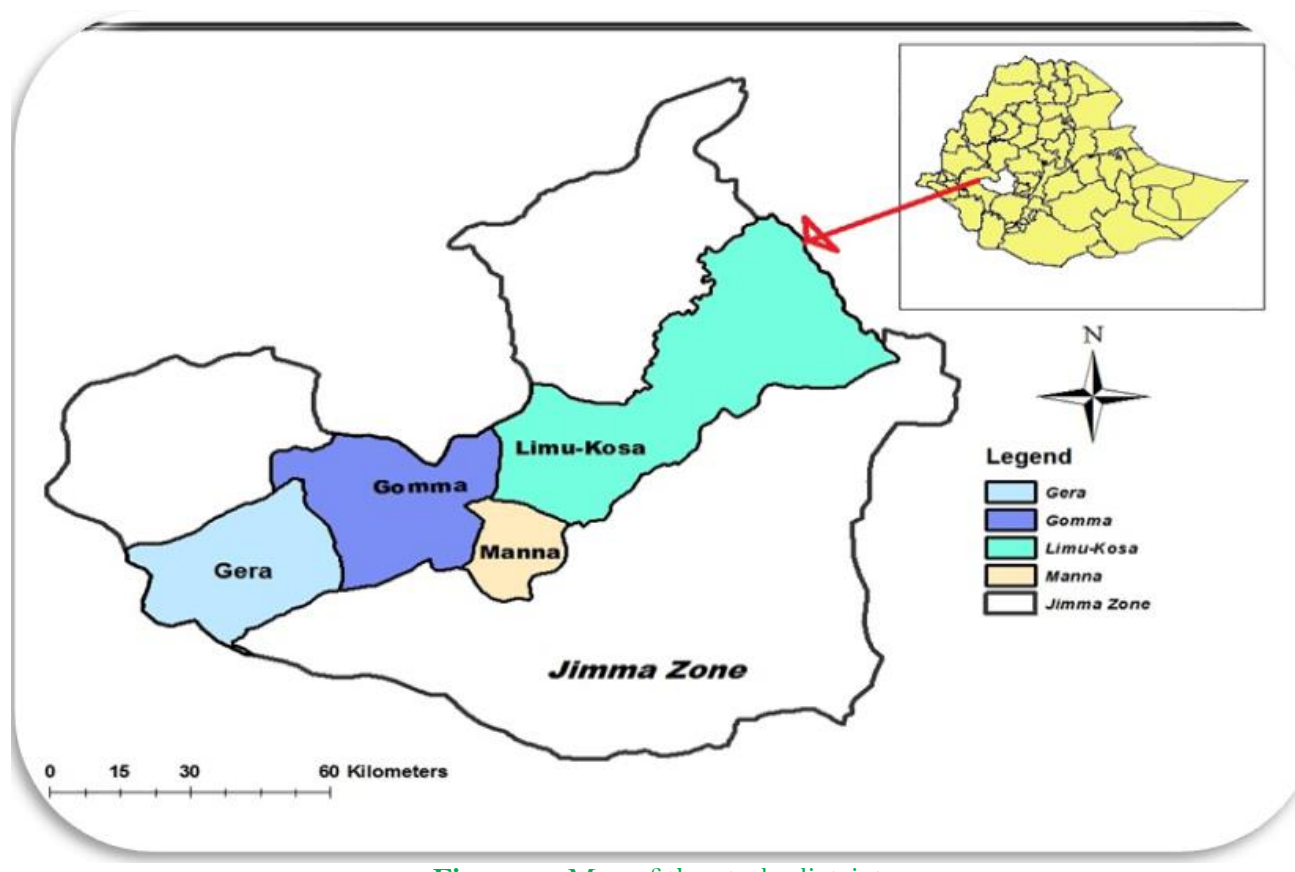

Figure-1. Map of the study districts.

Source: Manipulated by the authors from ARC GIS (2017).

\subsection{Sampling Procedure}

Multistage sampling technique was employed to select the population for the study which involved both purposive and random sampling techniques. First, districts were purposively picked, and secondly kebeles were selected using random sampling method. Finally, households were randomly chosen from the sampling frame exist at kebele level. A total of 205 households were selected for the study.

\subsection{Data Collection and Analysis}

Data was collected through structured questionnaire administered to sampled farmers from March 2017 to April 2017. All demographic, socio-economic, coffee production and utilization, technology use, adoption pathway, constraints of production and technology adoption were collected. Before the actual survey, the questionnaire was pretested in non-sampled villages. The pretest was not only used to test the appropriateness of the tool in collecting the required data but also to evaluate the trained enumerators on the capability of administering the questionnaire.

Information related to coffee production and utilization was gathered from the respondents. Households' socio demographic, institution and economic features were also collected. Data were cleaned, organized and analyzed using STATA version 14.2 software. Both descriptive and inferential statistics were used to analyze the gathered and cleaned data. The Kendall coefficient of concordance was used to assess the constraints against the production of coffee [12]. In our case, constraints were ranked from 1-10; 1 being the most constraining factor and 10 being the least constraining factor.

\section{Result and Discussion}

\subsection{Farmers' Demographic Structure}

The study was conducted on four coffee potential districts of Jimma zone in Oromia regional state. Total number of respondents interviewed was 205. Out of the total respondents, 95.1\% were male headed households and the rest were female headed.

\begin{tabular}{|c|c|c|c|c|c|c|}
\hline Variables & & $\begin{array}{l}\text { Gomma } \\
(\mathrm{N}=46)\end{array}$ & $\begin{array}{c}\text { Gera } \\
(\mathrm{N}=50)\end{array}$ & $\begin{array}{c}\text { Limu Kosa } \\
(\mathrm{N}=71)\end{array}$ & $\begin{array}{l}\text { Manna } \\
(\mathrm{N}=38)\end{array}$ & $\begin{array}{r}\text { Overall } \\
(\mathrm{N}=205) \\
\end{array}$ \\
\hline \multirow[b]{2}{*}{ Gender in \% } & Male & 95.7 & 98.0 & 94.4 & 92.1 & 95.1 \\
\hline & Female & 4.30 & 2.0 & 5.6 & 7.9 & 4.9 \\
\hline \multirow{5}{*}{ Marital status in \% } & Married living with spouse & 95.6 & 98.0 & 91.6 & 92.2 & 94.2 \\
\hline & Married living without spouse & 0.0 & 0.0 & 1.4 & 2.6 & 1.0 \\
\hline & Single/Never married & 0.0 & 0.0 & 1.4 & 0.0 & 0.4 \\
\hline & Divorced & 2.2 & 0.0 & 1.4 & 2.6 & 1.5 \\
\hline & Widowed & 2.2 & 2.0 & 4.2 & 2.6 & 2.9 \\
\hline \multirow{5}{*}{$\begin{array}{l}\text { Occupation of the } \\
\text { household head in \% }\end{array}$} & Agriculture self employed & 93.5 & 96.0 & 93.0 & 97.4 & 94.5 \\
\hline & Agriculture wage labor & 4.3 & 0.0 & 1.4 & 0.0 & 1.5 \\
\hline & Non agriculture self employed & 0.0 & 0.0 & 2.8 & 0.0 & 1.0 \\
\hline & Non-agricultural wage labor & 2.2 & 2.0 & 1.4 & 2.6 & 2.0 \\
\hline & Domestic work & 0.0 & 2.0 & 1.4 & 0.0 & 1.0 \\
\hline \multirow{5}{*}{$\begin{array}{l}\text { Education level of the } \\
\text { household head in \% }\end{array}$} & Non educated & 8.7 & 20.0 & 22.6 & 10.5 & 16.6 \\
\hline & Adult/religious education & 2.2 & 18.0 & 2.8 & 5.3 & 6.8 \\
\hline & Primary education $(1-8)$ & 65.2 & 56.0 & 56.3 & 68.4 & 60.5 \\
\hline & Secondary education $(9-12)$ & 23.9 & 6.0 & 18.3 & 15.8 & 16.1 \\
\hline & College education & 0.0 & 0.0 & 0.0 & 0.0 & 0.0 \\
\hline
\end{tabular}

Source: Survey result, 2017 
The marital status of the farmers showed that the majority of them were married and insignificant amount were widowed household heads. Regarding occupation, most of respondents were engaged on full time agricultural work on own farm. Out of the total respondents, the education level of more than halve of respondents were primary education and few were non-educated. Gomma and Manna districts have the least non educated respondents, and Limu Kosa have the highest non educated respondents Table 1.

The age of the respondents was examined as it is an important demographic factor to affect agricultural activities. The result showed non-significant difference among the districts in age of respondents. The mean age of the respondents was 47.08 years. Family size affects agricultural productivity and production as it is the proxy for labour. The survey result revealed that large mean family size was seen at Gomma district and the lowest mean family size existed at Limu Kosa district. The overall mean family size was 6.64. Table 2 showed statistically significant difference between districts in number of family size of the household at $5 \%$ significance level.

\begin{tabular}{|c|c|c|c|c|c|c|c|c|c|c|c|}
\hline \multirow[t]{2}{*}{ Variable } & \multicolumn{2}{|c|}{$\begin{array}{c}\text { Gomma } \\
(\mathrm{N}=46)\end{array}$} & \multicolumn{2}{|c|}{$\begin{array}{c}\text { Gera } \\
(\mathrm{N}=50)\end{array}$} & \multicolumn{2}{|c|}{$\begin{array}{c}\text { Limu Kosa } \\
(\mathrm{N}=71)\end{array}$} & \multicolumn{2}{|c|}{$\begin{array}{l}\text { Manna } \\
(\mathrm{N}=38)\end{array}$} & \multicolumn{2}{|c|}{$\begin{array}{c}\text { Overall } \\
(\mathrm{N}=205)\end{array}$} & \multirow[t]{2}{*}{ P-value } \\
\hline & Mean & S.E & Mean & S.E & Mean & S.E & Mean & S.E & Mean & S.E & \\
\hline Head age & 45.46 & 1.59 & 41.56 & 1.35 & 47.77 & 1.48 & 44.24 & 1.17 & 47.08 & 0.79 & 0.143 \\
\hline Family size & 7.02 & 0.33 & 6.76 & 0.27 & 6.38 & 0.28 & 6.50 & 0.33 & 6.64 & 0.15 & $0.049^{* *}$ \\
\hline
\end{tabular}

Source: Survey result, 2017.

The age of respondents across gender revealed that female headed households have larger age than male headed households. However, male headed households have high mean family size than female headed households which is significant at $10 \%$ significance level Table 3.

\begin{tabular}{c|c|c|c|c|c}
\hline \multirow{2}{*}{ Variables } & \multicolumn{2}{|c|}{$\begin{array}{c}\text { Male headed household } \\
(\mathbf{N = 1 9 5})\end{array}$} & \multicolumn{2}{c}{$\begin{array}{c}\text { Female headed households } \\
(\mathbf{N = 1 0 )}\end{array}$} & \multirow{2}{*}{ P-value } \\
\cline { 2 - 5 } & Mean & S.E & Mean & S.E & \\
\hline Age & 44.96 & 0.80 & 47.50 & 3.89 & 0.488 \\
\hline Family size & 6.70 & 0.16 & 5.40 & 0.72 & $0.066^{*}$ \\
\hline Note: * Indicate significance level at 10\%.
\end{tabular}

Source: Survey result, 2017.

\subsection{Land Ownership and Tenure Arrangement}

Land is the main irreplaceable factor of production in agricultural sector. The study result showed that the mean land size of the respondents is 2.14 hectares. However, large land size was seen at Gera and Limu Kosa. The study showed statistically significant difference between the districts in land size at $10 \%$ significance level. Coffee land holding of the study area revealed that Gera and Limu Kosa district's farmers holds as large coffee land. The small land size was observed at Gomma district. However, there was no statistically significant difference between districts in terms of coffee land size Table 4. The mean share of coffee land from total land is $69.6 \%$ which is high at Manna district. The land covered by coffee at Manna district is $77.4 \%$ which is by far higher than the rest of districts.

Table-4. Land holding and share of coffee by location.

\begin{tabular}{|c|c|c|c|c|c|c|c|c|c|c|c|}
\hline \multirow[t]{2}{*}{ Description } & \multicolumn{2}{|c|}{$\begin{array}{c}\text { Gomma } \\
(\mathrm{N}=46)\end{array}$} & \multicolumn{2}{|c|}{$\begin{array}{c}\text { Gera } \\
(\mathrm{N}=50)\end{array}$} & \multicolumn{2}{|c|}{$\begin{array}{c}\text { Limu Kosa } \\
(N=71)\end{array}$} & \multicolumn{2}{|c|}{$\begin{array}{l}\text { Manna } \\
(\mathrm{N}=38)\end{array}$} & \multicolumn{2}{|c|}{$\begin{array}{c}\text { Overall } \\
(\mathrm{N}=205)\end{array}$} & \multirow[t]{2}{*}{$P$ value } \\
\hline & Mean & S.E & Mean & S.E & Mean & S.E & Mean & S.E & Mean & S.E & \\
\hline $\begin{array}{c}\text { Coffee land in } \\
\text { hectares }\end{array}$ & 1.35 & 0.19 & 1.64 & 0.20 & 1.63 & 0.23 & 1.20 & 0.16 & 1.49 & 0.11 & 0.465 \\
\hline
\end{tabular}

Note: ***, * Indicate significance level at $1 \%$ and $10 \%$ respectively.

Source: Survey result, 2017.

Land holding among gender also revealed that male headed households have large mean land holding as compared to the female counterparts though no statistically significant difference. On other hands, coffee land holding by gender has also been seen. The result pointed out that male headed households have large coffee land relative to female headed counterparts. Despite the result, there is no significant difference between coffee lands among gender. The share of coffee land among male and female headed households showed coffee has covered $69.4 \%$ of male headed household's land and $81.6 \%$ of the female headed counterparts Table 5.

\begin{tabular}{|c|c|c|c|c|c|}
\hline \multirow[t]{2}{*}{ Description } & \multicolumn{2}{|c|}{$\begin{array}{l}\text { Male headed households } \\
\qquad(\mathrm{N}=195)\end{array}$} & \multicolumn{2}{|c|}{$\begin{array}{l}\text { Female headed households } \\
\qquad(\mathrm{N}=10)\end{array}$} & \multirow[t]{2}{*}{ P-value } \\
\hline & Mean & S.E & Mean & S.E & \\
\hline Mean land in hectares & 2.16 & 0.13 & 1.74 & 0.49 & 0.438 \\
\hline Mean coffee land in hectares & 1.50 & 0.11 & 1.42 & 0.52 & 0.886 \\
\hline Share of coffee in $\%$ & \multicolumn{2}{|c|}{69.4} & \multicolumn{2}{|c|}{81.6} & 0.995 \\
\hline
\end{tabular}

Source: Survey result, 2017. 
Number of plots affects the resource allocation and utilization of the farmers which in turn affect the gross margin of a farm. The study was tried to assess the number of coffee plots that farmers own. The result of the study showed that the mean number of coffee plot is 2.33 across the study districts. However, coffee land fragmentation is high at Gomma district and lower at Manna district (Table 6).

Table-6. Coffee plot holding by location.

\begin{tabular}{|c|c|c|c|c|c|c|c|c|c|c|}
\hline Gomm & \multirow{2}{*}{$\begin{array}{c}(\mathrm{N}=46) \\
\text { S.E }\end{array}$} & \multirow{2}{*}{$\begin{array}{l}\text { Gera } \\
\text { Mean } \\
\end{array}$} & \multirow{2}{*}{$\frac{(\mathrm{N}=50)}{\text { S.E }}$} & \multicolumn{2}{|c|}{ Limu Kosa $(N=71)$} & \multicolumn{2}{|c|}{ Manna $(\mathrm{N}=38)$} & \multicolumn{2}{|c|}{ Overall $(\mathrm{N}=205)$} & \multirow[b]{2}{*}{ P-value } \\
\hline Mean & & & & Mean & S.E & Mean & S.E & Mean & S.E & \\
\hline 2.46 & 0.18 & 2.18 & 0.16 & 2.46 & 0.15 & 2.09 & 0.17 & 2.33 & 0.08 & 0.310 \\
\hline
\end{tabular}

\subsection{Farmers' Coffee Farm Characteristics}

The study area is endowed with a good production environment for growing coffee with a combination of appropriate altitude, temperature, rainfall, soil type, and PH. Totally 539 coffee plots of 205 farmers were investigated on the survey. Farmers' perception on coffee plots' soil fertility showed that $37.85 \%$ of plots are good and $13.73 \%$ are poor in fertility. Gera district has relatively higher proportion of coffee plots and Gomma district has lower fertile plots according to farmers' traditional evaluation and perception. The slope of the coffee plots was also seen on the survey. The descriptive result of the study showed that $32.84 \%, 48.98$ and $18.18 \%$ of coffee plots have gentle, medium and steeply slope respectively. Farmers' evaluation of depth of the soil of the coffee plots showed that $50.1 \%$ has medium and $23 \%$ has deep soil. Gomma district has relatively high proportion of deep soil and Manna has the least. Regarding soil color, the majority of the plots' soil is red (42.49\%). Black and brown soil covers $38.03 \%$ and $19.48 \%$ of the total coffee plots Table 7 .

\begin{tabular}{|c|c|c|c|c|c|c|}
\hline Coffee plots' features & & $\begin{array}{l}\text { Gomma } \\
(\mathrm{N}=137)\end{array}$ & $\begin{array}{c}\text { Gera } \\
(\mathrm{N}=1111)\end{array}$ & $\begin{array}{c}\text { Limu Kosa } \\
(\mathrm{N}=195)\end{array}$ & $\begin{array}{l}\text { Manna } \\
(\mathrm{N}=96)\end{array}$ & $\begin{array}{c}\text { Overall } \\
(\mathrm{N}=539)\end{array}$ \\
\hline \multirow[t]{3}{*}{ Soil fertility in $\%$ from total plots } & Good & 34.30 & 48.65 & 34.87 & 36.46 & 37.85 \\
\hline & Medium & 51.11 & 45.05 & 50.26 & 44.79 & 48.42 \\
\hline & Poor & 14.59 & 6.30 & 14.87 & 18.75 & 13.73 \\
\hline \multirow[t]{3}{*}{ Slope in \% from total plots } & Gentle slope & 33.58 & 31.53 & 29.23 & 40.63 & 32.84 \\
\hline & Medium slope & 42.33 & 56.76 & 53.85 & 39.58 & 48.98 \\
\hline & Steeply slope & 24.09 & 11.71 & 16.92 & 19.79 & 18.18 \\
\hline \multirow[t]{3}{*}{ Soil depth in \% from total plots } & Shallow & 18.25 & 35.14 & 30.26 & 22.92 & 26.90 \\
\hline & Medium & 51.82 & 43.24 & 48.72 & 58.33 & 50.10 \\
\hline & Deep & 29.93 & 21.62 & 21.02 & 18.75 & 23.00 \\
\hline \multirow[t]{3}{*}{ Soil color in \% from total plots } & Black soil & 41.61 & 40.54 & 35.38 & 35.41 & 38.03 \\
\hline & Brown soil & 19.71 & 20.72 & 20.51 & 15.63 & 19.48 \\
\hline & Red soil & 38.68 & 38.74 & 44.11 & 48.96 & 42.49 \\
\hline
\end{tabular}

Note: Where $\mathrm{N}=$ total number of plots examined.

Source: Survey result, 2017.

The study was also tried to examine soil and water conservation methods and structures applied on farmers' coffee land. Accordingly, soil bunds and terrace were structures used by farmers relatively. About $77.5 \%$ of respondents do not used any conservation structures on their coffee land (Figure 2).

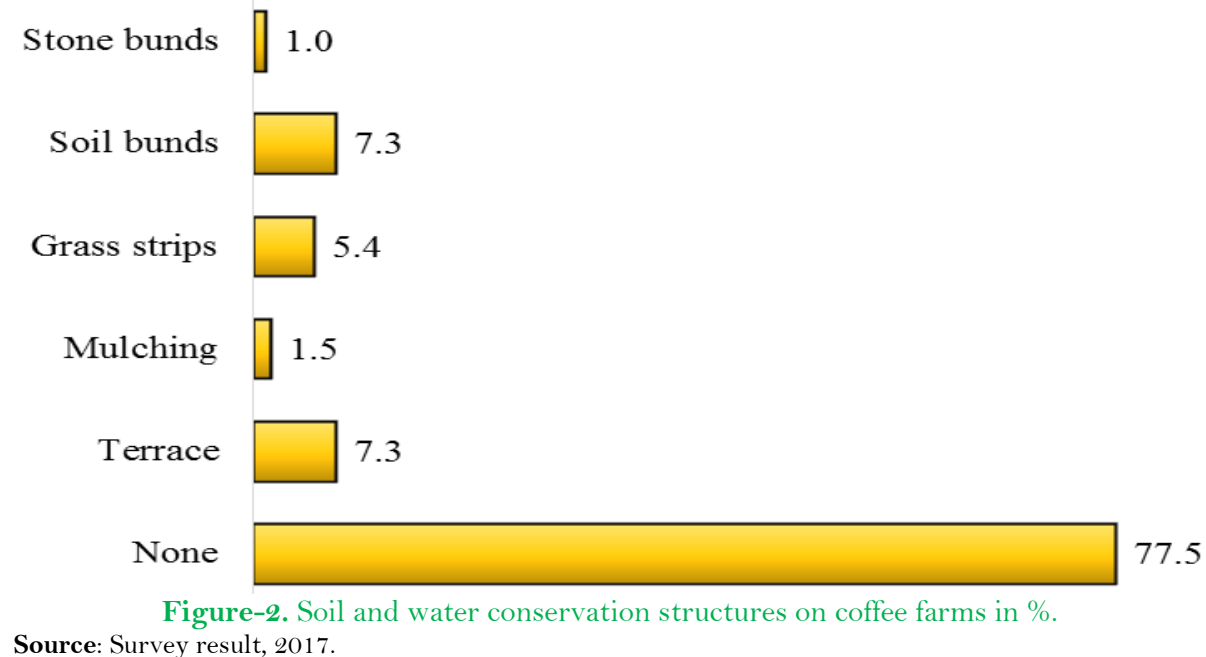

3.4. Farmers' Awareness for Improved Coffee Varieties

Awareness is the most crucial step for the adoption of agricultural technologies. Farmers were asked whether they have information about coffee cultivars with high productivity, disease resistant and high sensory quality. Accordingly, most of the farmers of each district knew the existence of improved coffee cultivars. 


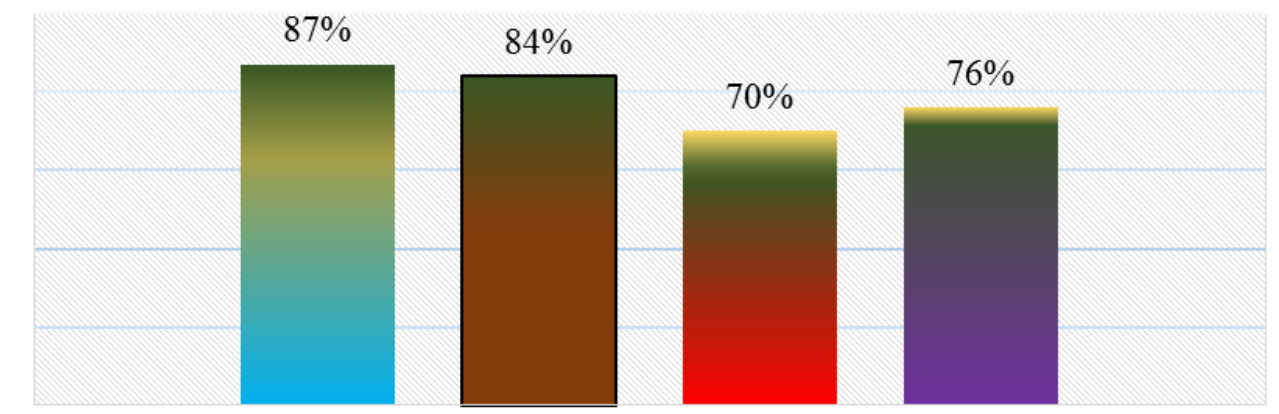

Awareness for improved coffee varieties

\section{-Gomma $\square$ Gera $\square$ Limu Kosa Manna \\ Source: Survey result, 2017 \\ Figure-3. Awareness for improved coffee cultivars by location.}

The information for the cultivars also differs among gender. The result pointed out that $80 \%$ of male headed households have awareness about the cultivars. Out of female headed households, $50 \%$ have information and $50 \%$ do not. The reason could be male headed households have more access to and socially delegated to meetings, training and farmers' field days.

\subsection{Coffee Productivity}

The overall objective of coffee production is yield. Coffee yield differ from location to location. Aside the coffee's morphological and physiological characteristics, different socio economic and geographical features affect the productivity of coffee. Despite the factors, high coffee yield was seen at Manna district and lowest clean coffee productivity per hectares was seen at Limu Kosa. The mean overall coffee yield per hectare was $769 \mathrm{~kg} / \mathrm{ha}$ which is higher than national average $(710 \mathrm{~kg} / \mathrm{ha})$ by $8.3 \%$. However, there was no significant productivity difference between study areas $(\mathrm{P}=0.768)$.

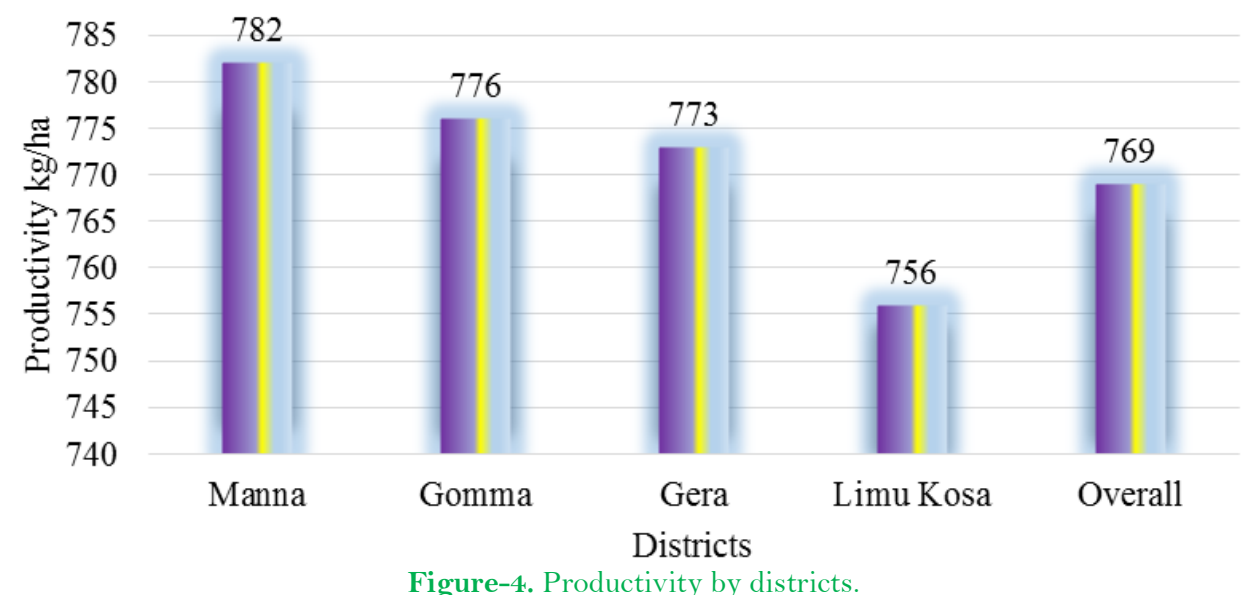

Source: Survey result, 2017.

Due different socio economic factors, productivity may differ among gender groups. Despite non-significant difference between the groups $(\mathrm{P}=0.520)$, male headed households' productivity ( $842 \mathrm{~kg} / \mathrm{hectare})$ is higher than the female headed households' productivity (766 kg/hectare).

\subsection{Source of Planting Material}

Seed and seedlings are two planting materials for coffee that has been diffused to users. The main source of seed and seedlings is government extension services. There is no certified coffee seed supplier in Ethiopia. However, Jimma agricultural research center produces seed and disseminate to districts according to their request and agro ecology. The districts disseminate the seed to model farmers and farmers' groups.

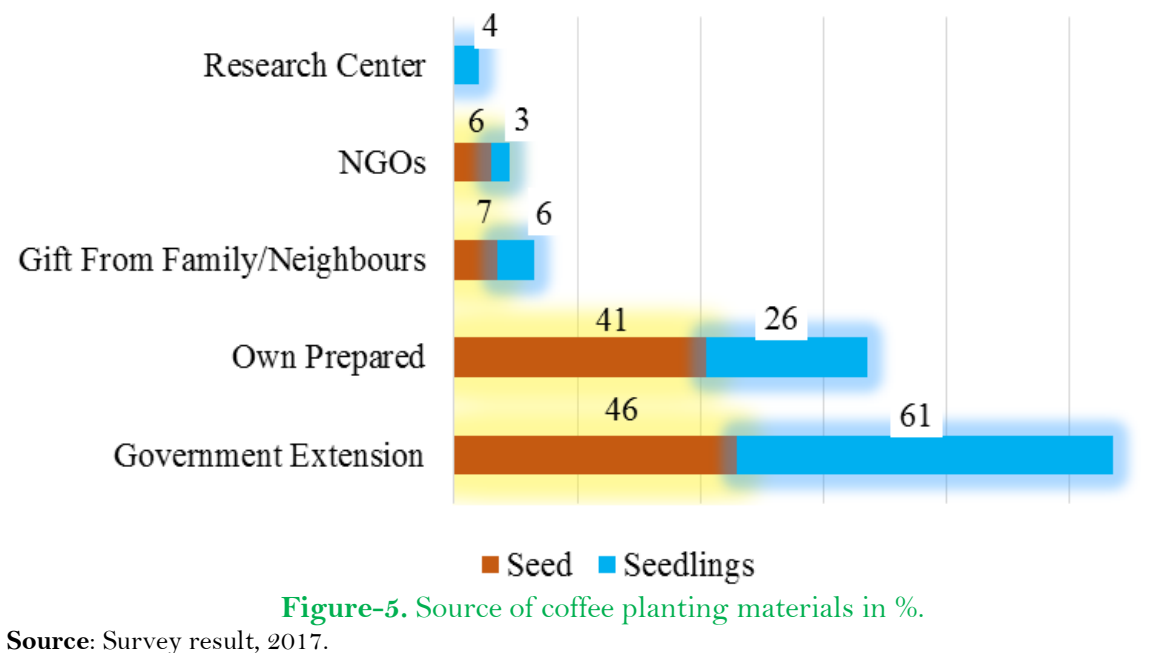


The extension also prepares seedlings at government nurseries which could be sold to farmers at low price. Accordingly, the result of the survey revealed that $46 \%$ and $61 \%$ of farmers got seed and seedlings respectively from government extension. Own prepared, gifts and NGOs are also the sources of the planting materials. Research center also supplies seedlings in some cases like for the establishment of demonstration and scaling out of improved coffee technologies (Figure 5).

\subsection{Sources of Information}

Information is the basic tool for the transfer of agricultural technologies. Different information dissemination and awareness creation method has been modeled and used by researchers. Training is one of the main methods among the models. The result revealed that $62 \%$ of respondents have got training on coffee production, postharvest handling and marketing.

Different bodies provided information for the farmers in the study area. The major one was government extension service which accounts for $61.1 \%$ of farmers. Research center specifically Jimma agricultural research center also contributes its share in providing information and knowledge for $19.1 \%$ of respondents (Figure 6 ).

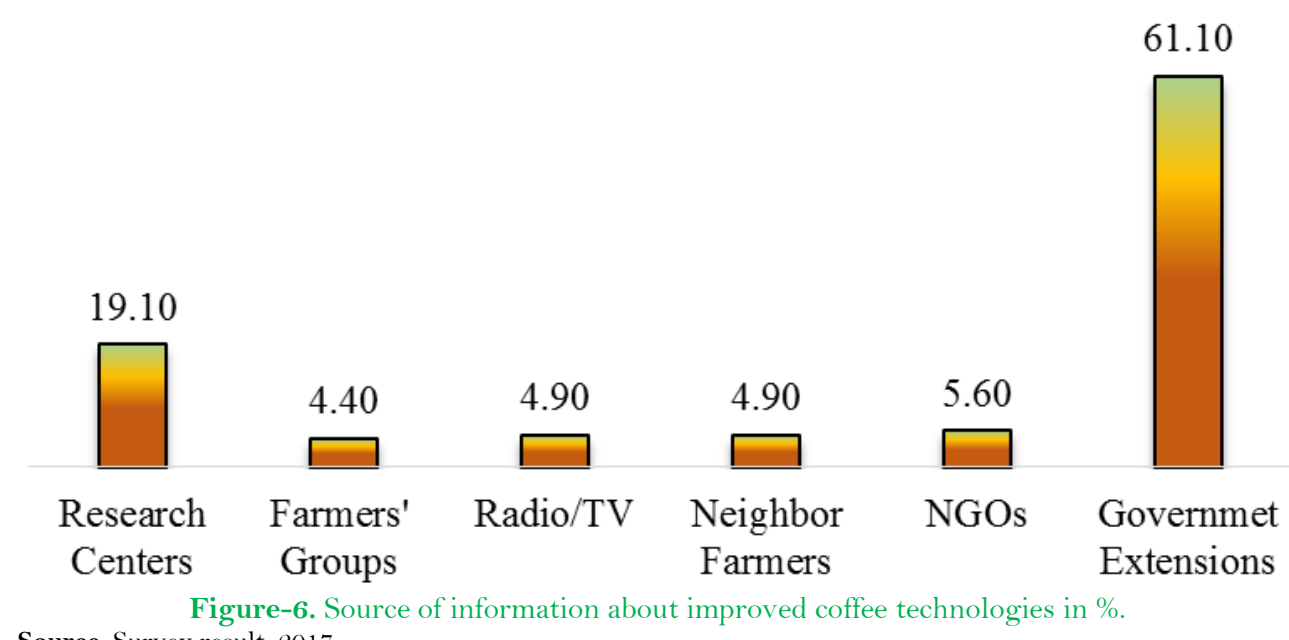

This study identified the interrelationship between training and adoption of improved coffee technologies. The result showed that $61 \%$ of respondents who have participated on coffee related training have adopted the improved varieties. However, 39\% of respondents who got training didn't adopted improved coffee varieties Figure 7.

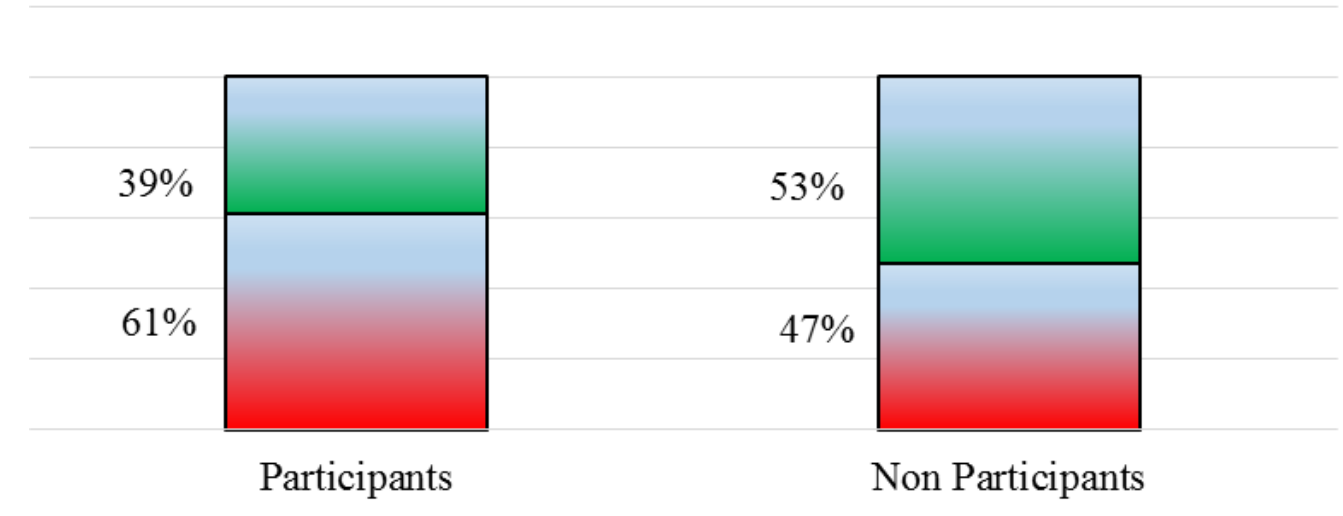

\section{口Adopters $\quad$ QNon adopters}

Figure-7. Descriptive relation of participation on coffee related training and adoption.

Source: Survey result, 2017

Different studies revealed that participation on farmers' field days positively and significantly affects adoption of improved agricultural technologies. This study was also identified the descriptive impact of participation coffee field days on adoption. The result revealed $68 \%$ of respondents who have participated on farmers' field days adopted the improved coffee varieties and $32 \%$ did not (Figure 8 ).

Non Participants

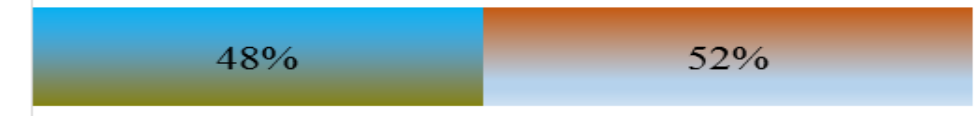

Participants

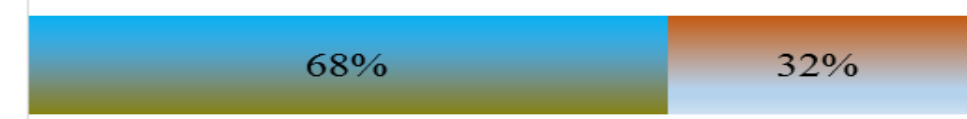

Figure-8. Descriptive relation of participation on coffee related field days and adoption. Source: Survey result, 2017. 


\subsection{Coffee Produce Utilization}

The utilization of coffee produce was also examined on the study area. The result of the study showed that the highest commercialization level was seen at Gera district (90.8\%) and relatively the lowest was recorded at Manna district (86.5\%). The mean commercialization level of coffee on the study area was $88.6 \%$. When we see the consumption of coffee, the mean consumption of coffee was $6.8 \%$ and the highest coffee consumers were farmers of Limu Kosa district (7.8\%). Generally, there is no wider difference in coffee consumption among the districts (Table 8).

Table-8. Utilization of coffee produce.

\begin{tabular}{c|c|c|c|c|c}
\hline Description & Gomma & Gera & Limu Kosa & Manna & Total \\
\hline Mean Production (kg/household) & 1828 & 1807 & 1453 & 1851 & 1697 \\
\hline Mean coffee sold (kg) & 1587 & 1641 & 1302 & 1601 & 1504 \\
\hline Mean coffee for other uses (kg) & 124 & 62 & 99.6 & 96.5 & 77 \\
\hline Mean coffee consumed (kg) & 117 & 110 & 114 & 125 & 116 \\
\hline Sale \% Commercialization) & 86.8 & 90.8 & 89.6 & 86.5 & 88.6 \\
\hline Consumption \% & 6.4 & 6.1 & 7.8 & 6.8 & 6.8 \\
\hline Source: Survey result.
\end{tabular}

\subsection{Perception on Improved Coffee Technologies}

Perception about the specific technology strongly affects farmers' adoption decision [13]. The respondents were asked to give their level of agreement on perception statements comparing the improved varieties with the local varieties. The agreement levels were arranged on hedonic scale of 1 to 10 (1 indicating strong agreement and 10 indicating strong disagreement to the statement). Accordingly, farmers strongly agree in high yield, vigorously and large canopy size and disease tolerance of improved coffee varieties relative to the local counterparts Table 9.

Table-9. Farmers' perception of important varietal attributes

\begin{tabular}{|c|c|c|}
\hline Coffee Characteristics & Mean Rank & Global Rank \\
\hline Coffee improved varieties have high yield & 3.52 & 1 \\
\hline Coffee improved varieties are vigorous and have large canopy & 5.54 & 2 \\
\hline Coffee improved varieties are disease tolerant & 5.71 & 3 \\
\hline Coffee improved varieties matures early & 5.86 & 4 \\
\hline Coffee improved varieties have good berry size & 6.06 & 5 \\
\hline Coffee improved varieties are insect tolerant & 6.23 & 6 \\
\hline Coffee improved varieties have good berry color & 6.76 & 7 \\
\hline Coffee improved varieties are drought tolerant & 6.92 & 8 \\
\hline Coffee improved varieties are frost tolerant & 7.16 & 9 \\
\hline Coffee improved varieties have good sensory quality (taste) & 7.25 & 10 \\
\hline Coffee improved varieties are labor demanding & 7.58 & 11 \\
\hline Coffee improved varieties are input demanding & 9.40 & 12 \\
\hline \multicolumn{3}{|c|}{ Kendall's coefficient of concordance $=0.187^{* * *}$} \\
\hline
\end{tabular}

\subsection{Constraints to Improved Coffee Adoption}

Agriculture is risky and uncertain sector of developing world economy. Production, marketing, financial, human and institutional factors are the most commonly known risks in agriculture. Coffee farmers were told ten major problems related to coffee production on their area to rank them based on their importance. The result of Kendall's coefficient of concordance summarized below showed that fluctuating coffee price is the most important problem ranked first. This was the problem raised by almost all farmers interviewed. The problem of coffee price is related to coffee global price which is set by giant coffee processing and marketing companies. The constraint ranked second was lack of reliable coffee market information. Own observation in this regard also showed farmers sell their product to local traders without having any know how about update coffee price. The third important problem identified by the coffee farmers was lack of coffee seed and seedling varieties preferred Table 10.

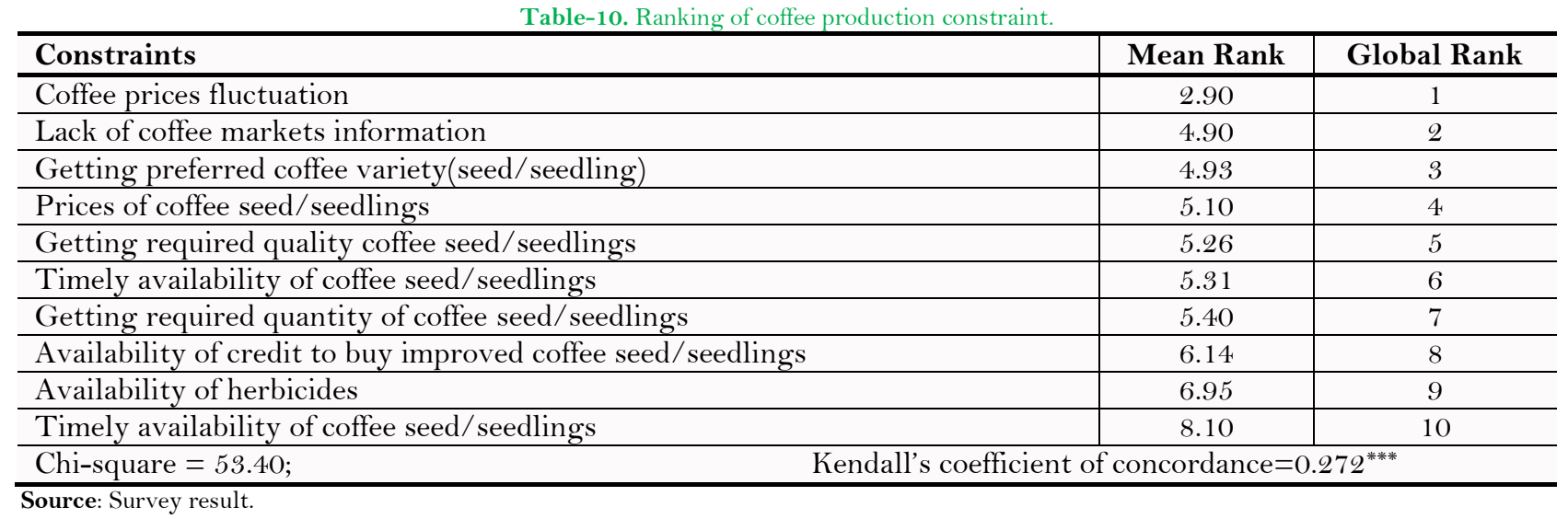

\section{Conclusions and Recommendations}

The study was aimed to identify major coffee production problems that affected coffee farmers' production and productivity. The result of the study identified three main coffee related problems raised and ranked by farmer namely coffee price fluctuation, lack of coffee market information and lack of improved coffee seed and seedlings. Based on the above findings, the study has drawn the following implication. 
- Strengthening cooperatives and unions: Cooperatives and unions on the study area collect both dry and red coffee in relatively attractive price. The outlet has reduced additional transaction cost and also eliminates/reduces unnecessary chain actors such as brokers or assemblers. Farmers also collects dividend in proportion to the coffee they supplied to cooperatives. However, the main drawback of this market outlet is that they do not pay the money on the day farmer sale coffee. Farmers stay for a weeks or even months to collect the money. This makes the farmers to not sell their coffee to cooperatives which in turn leads to sell for local traders and brokers that fluctuates coffee price significantly. Therefore, strengthening the financial capacity of cooperatives and union should be a good option for farmers to sell their coffee product to these outlets so that coffee price could be modified and farmers could collect the margin they deserve.

- Supply of improved coffee seeds and seedlings: The study result identified lack of preferred coffee varieties' planting materials as the main constraint on the study areas. Encouraging smallholder farmers in supplying planting materials (seed/seedlings) to replace aged coffee for improved coffee technologies is a critical option to be given emphasis by stakeholders such as extension, research centers, Universities and NGOs. On other hands, government nurseries need to emphasize on seedling distribution to their maximum capacity.

- Sustainable seed system: There is no formally recognized enterprise which multiplies and supply coffee seed. Its only research center that have limited seed multiplication sites which is incapable to satisfy huge and raising demand for improved coffee seed. There is high mismatch between coffee seed demand and supply. Therefore, concerning bodies need to be concerned the way coffee seed sources would be established for each coffee producing area.

\section{References}

[1] ICC International Coffee Council, "CC development strategy for coffee," presented at the International Coffee Council 105th Session, London, 2010.

[2] K. F. Wiersum, "Indigenous exploitation and management of tropical forest resources: An evolutionary continuum in forest-people interactions," Agriculture Ecosystem Environment, vol. 63, pp. 1-16, 1997. Available at: https://doi.org/10.1016/s01678809(96)01124-3.

[3] DFSC and IPGRI, Forest genetic resources conservation and management: Overview, concepts and some systematic approaches vol. 1. Rome, Italy: International Plant Genetic Resources Institute, 2001

[4] L. C. Olmos, E. Duque, and E. Rodriguez, "State of the art of coffee drying technologies in Colombia and their global Development," Espacios, vol. 38, pp. 27-37, 2017.

[5] G. Adugna, B. Bellachew, T. Shimber, E. Taye, and T. Kufa, Coffee diversity and knowledge. Addis Ababa, Ethiopia: Ethiopian Institute of Agricultural Research, 2008.

[6] USAID, "Ethiopian coffee industry value chain analysis. Profiling the actors, their interactions, costs, constraints and opportunities. Chemonics International Inc. [Accessed 18 June 2010]," 2010.

[7] I. Pokorná and L. Smutka, "What is the structure of the coffee market: Can the real poor benefit from the coffee trade? Memeographed paper; electronic copy. Czech University of Life Sciences, Faculty of Economics and Management, Department of Economics. Available: http://ssrn.com/abstract=1734902," 2011.

[8] A. Bizualem, G. Degye, and S. Zekarias, "Analysis of marketed surplus of coffee by smallholder farmers in Jimma zone, Ethiopia," Journal of Biology, Agriculture and Healthcare, vol. 5, pp. 242-251, 2015.

[9] G. Dessalegn and S. Kebebew, "Evaluating coffee market structure and conduct in Bench-Maji zone, South West Ethiopia," Journal of Agricultural Economics, Extension and Rural Development, vol. 2, pp. 156-163, 2014.

[10] ECTDMA / Ethiopian Coffee and Tea Development and Marketing Authority, "Coffee productivity and quality improvement package training manual (Amharic); Ministry of Agriculture and Rural Development, Addis Ababa, Ethiopia," 2016.

[11] JANRD/Jimma Zone Agricultural and Natural Resource Development, "Profile and features of districts," Unpublished Report; Jimma, Ethiopia2016.

[12] P. A. Pinamang, N. A. Eyram, A. Nimo-Wiredu, D. Adogoba, B. Nsiah-Frimpong, J. Haleegoah, A. Adu-Appiah, B. Owusu-Asante, K. Adofo, and E. Baafi, "Root and tuber crops technologies adoption and impact study in Ghana: The case of improved sweet potato technologies," Final Report to the West Africa Agricultural Productivity Program, Ghana2017.

[13] A. A. Adesina and M. M. Zinnah, "Technology characteristics, farmers' perceptions and adoption decisions: A Tobit model application in Sierra Leone," Agricultural Economics, vol. 9, pp. 297-311, 1993. Available at: https://doi.org/10.1016/0169$5150(93) 90019-9$. 